\title{
A note on the revisited Uppsala internationalization process model - The implications of business networks and entrepreneurship
}

\begin{abstract}
In their article from 2009, Johanson and Vahlne suggest a reformulation of the Uppsala internationalization process model by incorporating business network theory and entrepreneurship theory into the model. The present paper makes a critical examination of this reformulation. The overall conclusion is that several issues have to be addressed regarding the relationship between business networks and firms' internationalization, the meaning of entrepreneurship as well as the possibility to combine business network theory and entrepreneurship theory in the Uppsala model before the full potential of such an incorporation can be realized.
\end{abstract}

\section{INTRODUCTION}

The Uppsala internationalization process model was launched in a paper by Johanson and Vahlne in 1977 (Johanson \& Vahlne, 1977) and, ever since, it has been used as a platform for further studies of the internationalization process of firms by different scholars. In several papers written since the 90's, the authors have looked back at the model (Johanson \& Vahlne 1990; 2003; 2006;). In a comprehensive article published in 2009 in this journal, The Uppsala internationalization process model revisited: From liability of foreigness to liability of outsidership, Johanson \& Vahlne suggest a reformulation of the model, that in a fundamental way differ from the model of 1977, especially regarding internationalization as an entrepreneurial process in a business network context. In recent writings by the authors and other scholars the revisited Uppsala model seems to be received as a more appropriate way to analyse firms' internationalization behaviour (see e.g. Schweizer, Vahlne \& 
Johanson 2010; Santangelo \& Meyer 2011; Johanson \& Vahlne 2013; Casillas \& Moreno-Menendez 2014; Sui \& Baum 2014; Blankenburg Holm, Johanson \& Kao 2015; Oehme \& Bort 2015).

We argue, though, that the consequences of incorporating business network theory and entrepreneurship into the model need more considerations before it can be claimed that this will increase our understanding of the basic features of a firm's internationalization behaviour in a profound way. For instance, what is the relationship between the characteristics of the firm's business network and its foreign investment behavior in terms of pace, direction and level of commitments? In what way can the concept of liability of outsidership add to our understanding of a firm's internationalization process? What type of entrepreneurship theory is appropriate for developing the Uppsala model? Is it possible to combine the business network theory and entrepreneurship theory in one and the same model?

In the following, therefore, the revisited model of Johanson and Vahlne (2009) will be critically examined by looking at these consequences. More specifically, this paper consists of three sections: The first deals with the Uppsala model in a business network theory context with a special focus on liability of outsidership and the development of business relationships. The second section discusses the fit between the Uppsala model and the model of entrepreneurship, suggested by Johanson and Vahlne (2009). The third section focuses on some issues related to the compatibility between business network theory and entrepreneurship in the context of the Uppsala model.

\section{BUSINESS NETWORK THEORY AND THE UPPSALA MODEL}

One important trait of the ' 77 model was the assumption that a firm's market is more or less equivalent to a country market (Johanson \& Vahlne 1977). In the revised model, the country market concept is substituted by a perception of the foreign market as a business network (Johanson \& Vahlne, 2009). What does this change imply? 
In the revised model, the problem of lack of foreign market knowledge, to a large extent reflecting "liability of foreignness", is substituted by not having a position in the foreign network, referred to as "liability of outsidership" (Johanson \& Vahlne 2009:2015). In line with business network theory, this change reflects the crucial difference between being an insider and being an outsider in relation to a specific business network (Håkansson \& Snehota 1995; Uzzi 1996, 1997; Ford 1997; Mc Evily \& Zaheer 1999; Gulati, Nohria \& Zaheer 2000). Consequently, internationalization is conceptualized as the process of a firm trying to change its network position from outsidership to insidership (Blankenburg Holm, Johanson \& Kao 2015). This means that the difference between the home market and the foreign market is related to the firm's business context rather than the country's border.

\section{Liability of foreignness and liability of outsidership}

For the internationalization of firms and models describing the process, it is probably more appropriate to consider the foreign market to be a business network rather than a country market. However, outsidership is a general phenomenon in business network theory concerning every network, domestic or foreign, in which the firm is not embedded. In principle, the main difference between a domestic network and a foreign one is the liability of foreignness ${ }^{1}$. Consequently, and somewhat paradoxically, one might argue that it is the liability of foreignness, and not that of outsidership that is the crucial element in a model on internationalization. Liability of outsidership is important because it reflects the difficulties of establishing a position in a network from "outside", but there is no difference between foreign networks and domestic ones in that sense. A fundamental assumption in business network theory is that all firms are in some way or another "insiders" in a business network (with the possible exception of new ventures). So, even if this is an important element in the theory as such, the point that insidership in relevant networks is required does not tell us more specifically about the requirement for internationalization, only about the preconditions for extending business in general. This is also implicitly acknowledged by Johanson \& Vahlne in their conclusion that the larger the psychic distance, the more difficult it is to build new relationships. They note that this "is the effect of liability of foreignness" (Johanson \& Vahlne 2009:1414), which is another way of saying that the 
crucial difference between domestic and foreign networks is liability of foreignness rather than liability of outsidership.

Thus, the liability of outsidership in relation to foreign networks needs to be developed to contribute to our understanding of firms' internationalization. Otherwise it tells us more or less the same story as liability of foreignness. One possible way of doing this is to start with the proposition that while liability of foreignness is originally described as the cost of doing business abroad (Hymer 1976; Zaheer 1995) - a discrete border effect - liability of outsidership can be looked upon as a continuous distance effect (Beugelsdijk \& Mudambi 2013). A firm's perceived outsidership is related to the distance between its current business and the relevant foreign network. Consequently, the issue of casual relationship between a firm's perceived outsidership and its internationalization can be addressed by analyzing the characteristics of the business network in which the firm is embedded, and how such embeddedness influence the distance to a potential foreign network. There is ample evidence that network embeddedness influences the behavior of firms (Polyani 1957; Granovetter 1985; Grabher 1993; Dacin, Ventersca \& Beal 1999; McEvily \& Zaheer 1999; Moran 2005; ChamleeWright \& Myers 2008). Therefore, a reasonable assumption is that the characteristics of the business network in which a firm is embedded influences both the possibility of a firm to becoming an insider in a foreign network and the further development of the firm's foreign business.

A common distinction is often made between structural embeddedness and relational embeddedness (Dacin, Ventresca \& Beal 1999). Structural embeddedness focuses exclusively on "whom one knows" while relational embeddedness deals with "how well one knows them" (Moran 2005:1130). Structural embeddedness highlights the advantage a firm can derive from its position in a business network, while relational embeddedness deals with the advantage of learning and the exchange of information in dyadic, close relationships (Gulati 1998; Nahapiet \& Goshal 1998; Lane \& Lubatkin 1998; Hansen 1999). Both of these aspects of a firm's embeddedness can be used to increase our understanding of the internationalization process and the role of liability of outsidership. 
Take structural embeddedness first. A common issue in the discussion of a firm's structural embeddedness is the advantage of open versus closed networks. (Burt 1992; Coleman 1988). The advantage associated with open networks results from diversity of information and the firm's access to brokerage opportunities by bridging otherwise disconnected groups. It has to do with the position of the firm in its network and to what extent this position furnishes access to unique, non-redundant information (Walker, Kogut \& Shan 1997; Oehme \& Bort 2015). The advantage of closed networks, in contrast, is related to the social capital created in a close-knit network. Such social capital will have a positive effect on the production of social norms and sanctions that facilitate trust and cooperative exchanges (Gargiulo \& Benassi 2000).

The Uppsala model is basically a model of the recognition and exploitation of opportunities associated with foreign risk. Foreign risk is a product of the uncertainties associated with operating in foreign markets abroad and of commitments made in these markets (Johanson-Vahlne 1977, 2009; Figuera-de-Lemos, Johanson \& Vahlne 2011). Both open and closed networks might affect the firm's internationalization behavior in line with the Uppsala model. First, it has been demonstrated that if a firm is embedded in an open network, it is easier for it to recognize business opportunities, including opportunities in foreign markets (Moran 2005; Zaheer\& Bell 2005). This rests on the assumption that, if a firm's business network is rich with "structural holes", it may provide the firm with information about new opportunities (Burt 1992; Gargiuolo \& Benassi 2000; Zaheer \& Bell 2005). For instance, if a firm has a brokerage role between a supplier in the home country and a customer in a foreign country, this will create a potential for arbitrage that might lead to increased foreign business for the firm (Walker, Kogut \& Shan 1997).

Secondly, it has also been demonstrated that the possibility to exploit a business opportunity is dependent on the tightness of the firm's network. It has been argued that closed networks facilitate the transfer of knowledge and reduce the firm's risk associated with knowledge exchange because of the social capital fostered in such a network (Moran 2005). For instance, if there is a relation between the firm's supplier at home and its customer abroad, the risk of the firm investing resources in exchange with these counterparts in order to develop a business opportunity will be lower because a 
closed network is conducive to cooperation and minimizes opportunistic behavior (Walker, Kogut \& Shan 1997). So, even if open networks facilitate discovery of opportunities in the foreign market, closed networks might be conducive to the exploitation of these opportunities. This reasoning leads to what has sometimes been called the "paradox of embeddedness" (Uzzi 1997), whereby there is a trade-off between network structures that guarantee "safety" for cooperation and the minimization of risk, on the one hand, and network structures that optimize flexibility and the recognition of opportunity on the other (Gargiulo \& Benassi 2000).

The ability to exploit opportunities, though, is also dependent on relational embeddedness, that is on how deep, in terms of mutual dependence and trust, the firm's relationships are with other business actors in the network. It has been demonstrated that relational embeddedness has a positive impact on the outcome of innovation (Moran 2005). The reason for this is that innovations are more likely to be characterized by the exchange of intangible resources and mutual learning, paths that are uncertain, vague and risky for both the firm and its counterparts. Strong ties provide a better conduit for actually transferring and exchanging complex issues and ideas (Hansen 1999; Anderson, Forsgren \& Holm 2002). In line with the assumption that the internationalization process is an entrepreneurial one (Jones \& Coviello 2005) in which the firm experiences a "liability of newness" (Mudambi \& Zahra 2007), internationalization will often involve a movement away from established practice and therefore introduce substantial risk (Moran 2005). When the firm embarks on risky paths, confidence in the quality of the resources received becomes more important (Krackhardt 1990; Uzzi 1996). A reasonable conclusion, therefore, is that deep relationships with other business actors in the firm's business network will facilitate the establishment of a position in a foreign business network in order to exploit and develop a business opportunity.

It should be pointed out that a corresponding analysis is also applicable for the potential foreign network. For instance, if that network is open and/or dominated by arms'-length relationships, the firm's perceived outsidership concerning opportunity discovery is probably lower than if the network is closed and dominated by deep relationships between actors (Coviello 2006). At the same time, such a network might be less conducive for developing and exploiting the opportunities 
identified owing to uncertainty about cooperation, and losses caused by "defection and opportunism" (Gargiulo \& Benassi 2000: 193).

To summarize, an appropriate analysis of the role of liability of outsidership in the internationalization process of firms needs to start by looking into the structure of the firms' existing network and the characteristics of the dyadic relationships each firm has with different counterparts in its network. A tentative conclusion from the reasoning above is that an open network might reduce the firms' liability of outsidership associated with the ability to discover business opportunities in a foreign network, but might at the same time increase the liability of outsidership concerning the possibility to develop and exploit these opportunities. It is more problematic to guard an open network from foreign risk and to secure the quality of exchange of necessary resources compared to a closed one. Furthermore, a closed network, in which the firm is involved in deep relationships with other actors, implies access to social capital. The more social capital available to a firm, the fewer resources it needs to manage existing relationships and the more resources it can dedicate to the development of a business opportunity and the establishment of new relationships in the foreign market (Walker, Kogut \& Shan 1997). From this, it follows that the higher the foreign risk arising from perceived market uncertainty and the level of investment needed to exploit a business opportunity, the greater the need for the firm to have access to social capital linked to deep relationships in a closed network.

By applying the rich literature about how network embeddedness influences firm behavior, it is possible to develop the concept of liability of outsidership and to discuss how a firm's perceived outsidership might influence the internationalization process. The reasoning above opens up an interesting discussion about the trade-off between "flexibility" and "safety" (Gargiulo \& Benassi 2000). Or, expressed differently, the issue becomes one of how the firm can strike a balance between networks that reduce the liability of outsidership in the opportunity discovery phase of the internationalization process, and networks that reduce it in the opportunity development phase. This is a fascinating area for future research. 


\section{Internationalization as a relationship development process}

Johanson and Vahlne claim that the internationalization process is "similar to the relationship development process and the opportunity development process" (Johanson \& Vahlne 2009: 1419). In fact they posit that internationalization is best understood as a by-product of a firm's efforts to improve its position in its network (Schweizer, Vahlne \& Johanson 2010). We claim that a more fruitful approach would be a model considering these processes independently in order to elaborate on how the development of a firm's business relationships influences its foreign operations (Jones \& Coviello 2005). For instance, one interesting issue is how the firm's embeddedness in existing business relationships affects the incremental behavior and path-dependence of firms' internationalization. On one hand, we might argue that applying business network theory implies a stronger tendency for a firm to employ an incremental approach compared to the ' 77 model, because developing business relationships in a foreign context is a laborious and time-consuming process, especially if exploiting the opportunity abroad involves substantial risk and the exchange of intangible resources (Forsgren, Holm \& Johanson 2005). On the other hand, business network theory also tells us that the firm's lack of foreign market knowledge - so important in the old model - is less of a constraint, because such knowledge is partly accessible through the firm's business counterparts, and does not only rely on the firm itself. Expressed differently, the barrier in terms of the liability of outsidership is less severe than the "old" Uppsala model would imply. This might lead to a less incremental and path-dependent internationalization process. Which of these two forces will dominate in the individual firm is basically an empirical question.

In line with the reasoning above on embeddedness and firm behavior, a relevant issue is how a firm's existing business relationships affect the timing of the firm's internationalization process. Earlier research indicates that the level of embeddedness of a firm's business network is positively related to its ability to develop new competences (Andersson, Forsgren \& Holm, 2002). If we assume that such competences will increase its strength in the foreign market, it follows that the firm's internationalization process will be faster and less laborious than would otherwise be the case. But we also know that the development of relationships and competence is a resource-demanding process that 
competes with other processes, such as the firm's attempts to establish a position in a foreign market.

For instance, although there are some indications that, having developed strong business relationships with domestic counterparts, firms are more reluctant to enter foreign markets (Benito, Larimo, Narula \& Pedersen 2002. See also Autio,Sapienza \& Almeida 2000), it is also claimed that the social capital associated with such a network implies that the firm will have more resources to invest in new adventures because of less need to manage existing relationships (Walker, Kogut \& Shan 1997). Future research should address how these counteracting forces affect the shape and direction of the internationalization process.

\section{ENTREPRENEURSHIP AND THE UPPSALA MODEL}

In the revised version, Johanson and Vahlne claim that a step forward in the analysis of the internationalization process of firms would be to combine entrepreneurship with the business network perspective (Johanson \& Vahlne 2009: 1419). They claim that Kirzner's concept of entrepreneurial alertness offers a suitable starting point for such a combination because of his analysis of the entrepreneurial discovery of opportunities. The main reason for applying Kirzner's view is that opportunity recognition is largely seen as "accidental" rather than as a result of opportunity-seeking activities. In contrast to, e.g Shumpeter's view, in which opportunities are created by entrepreneurs, in the revisited Uppsala model, opportunity recognition results from the discovery of the hitherto unknown, based on alertness and a readiness to be surprised (Schweizer, Vahlne \& Johanson 2010).

\section{Kirzner and the Uppsala model}

In many ways, it is a reasonable strategy to start with Kirzner as he has inspired so much of the research on entrepreneurship since his book on competition and entrepreneurship was published (Kirzner 1973). However, we claim that Kirzner's view is also radically different from the core of the Uppsala model for the following reasons: First, although Kirzner equips the entrepreneur with attributes such as alertness and boldness, his conceptualization of entrepreneurship serves a purely instrumental function: to explain market clearing (Kirzner 1997; Foss \& Klein, 2010). Or as Kirzner 
put it himself: “... my own work has nothing to say about the secrets of successful entrepreneurship. My work has explored, not the nature of the talent needed for entrepreneurial success, nor any guidelines to be followed by would-be successful entrepreneurs, but, instead, the nature of the market process set in motion by the entrepreneurial decisions (both successful and unsuccessful ones!)” (Kirzner 2009:145). In fact, Kirzner insists that "ownership and entrepreneurship are to be viewed as completely separate functions. Once we have adopted the convention of concentrating all elements into the hands of pure entrepreneurs, we have automatically excluded the asset owner from an entrepreneurial role. Pure entrepreneurial decisions are by definition reserved by decision-makers, and nothing else" (Kirzner, 1978: 47). It is a metaphor of the entrepreneur rather than the entrepreneurial function that is the centre of the analysis (Foss \& Klein 2012). Kirzner's focus is neither the discovery process, nor the opportunity development process, and, consequently, is of limited value for the Uppsala model, in which the core is the interplay between market opportunities, firms' resources and foreign investments.

Second, the Uppsala model is a risk management model (Johanson \& Vahlne 1977, Figuero de-Lemos, Johanson \& Vahlne 2011). In Kirzner's treatment, the entrepreneur does not suffer from any substantial risk for the simple reason that he invests no (or very limited) resources. He performs “...only a discovery function, rather than an investment function” (Foss \& Klein 2012: 57). In a model in which "foreign risk" attributable to investments in foreign markets is crucial, Kirzner's heavy emphasis on "socially-productive ideas" rather than on investment in resources (Kirzner \& Sautet 2006) is both problematic and has little value for understanding how the firm handles the risk it is exposed to in its internationalization process.

Third, experiential learning, incremental behavior and path dependence are important concepts of the Uppsala model. It is a processual model about on-going business activities. This approach goes clearly beyond Kirzner's interest in what constitutes entrepreneurship (Foss \& Klein 2012:71). Or, expressed differently, Kirzner's model is not about processes, but deals with entrepreneurship as a question of opportunity discovery, irrespective of history or future. Consequently, although opportunity discovery is crucial in a model on internationalization because 
"knowledge of opportunities and problems is assumed to initiate decisions" (Johanson \& Vahlne 2009:1418), Kirzner's analysis is of limited value to understand the process of internationalization.

Thus, Kirzner's model on entrepreneurship is so different from the core of the Uppsala model that it is questionable whether a fruitful combination and therefore a "step forward" in terms of developing the model is really possible. It should be pointed out, though, that Johanson \& Vahlne claim that Kirzner's view offers a starting point for analyzing entrepreneurship in relation to the Uppsala model, rather than something they incorporate in its entirety. For instance, in their discussion of the importance of prior knowledge of the discovery process based on Shane (Shane 2000) and of the development of opportunities as a relationship development process, they go beyond Kirzner's analysis and suggest that he "exaggerates the role of serendipity" (Johanson \& Vahlne 2009: 1419) in entrepreneurship.

\section{Entrepreneurial judgement and the Uppsala model}

There are fruitful alternatives to to the one presented by Kirzner for incorporating the entrepreneurial dimension into the Uppsala model. The most obvious is Knight's treatment of entrepreneurship (Knight 1921). Knight identifies the entrepreneur as a recipient of pure profit as a reward for bearing the costs of investing in an "unknown future" (Casson 2003; Foss \& Klein 2012). Although Knight's entrepreneur is an individual (or team of individuals) with special skills and perceptions of the future (Casson 2003), in contrast to Kirzner's understanding, entrepreneurship is closely linked to the firm and its resources. Knight's entrepreneurs "establish firms... because their beliefs about the future cannot be easily articulated and communicated to existing resource owners" (Foss \& Klein 2012:85). If Kirzner emphasizes opportunities waiting to be discovered (Shane \& Venkataraman 2002), Knight's focus is on investments based on the entrepreneur's subjective expectations about an uncertain future.

In an attempt to develop the theory of entrepreneurship from Knight's perspective, it has been suggested that entrepreneurship is basically about "judgement". In this approach, "entrepreneurs are modelled as decision-makers who invest resources based on their judgement of future market conditions, investment that may or may not yield positive return" (Foss \& Klein 2012: 20). Such 
judgement is the (largely tacit) ability to make decisions under conditions of genuine uncertainty, decisions that turn out to be successful ex post (Langlois 2007).

The latter view on entrepreneurship harmonizes better with the Uppsala model for the following reasons: First, entrepreneurial decisions about foreign commitments are performed within the context of firms rather than independent of them. Second, entrepreneurship is an activity characterized by experimentation and learning. Third entrepreneurial decision-making is a process rather than a matter of opportunity discovery. Fourth, foreign commitments based on entrepreneurial judgement imply risk. In contrast to Kirzner, this view is more compatible with a model that handles risk exposure by muddling through and incremental behavior. Fifth, Knight's entrepreneur bases his decision-making not only on (unique) expectations about the future, but also on the firm's existing resources. This is more in line with the suggestion by Johanson \& Vahlne (2009:1423) that one should look upon the entrepreneurial process as an effectuation process, in which the characteristics of existing resources, including business relationships, influence the space of opportunities that the entrepreneur explores (Sarasvathy 2001; Foss \& Klein 2012). The "affordable loss principle" as part of the effectuation logic is also a natural element in the manner in which the Uppsala model conceptualizes risk management in foreign ventures (Kalinic, Sarasvathy \& Forza 2014).

Thus, Knight's perspective on the entrepreneur and the conceptualization of entrepreneurial judgement probably has more to contribute to the Uppsala model than Kirzner's model of entrepreneurship. It also opens up some intriguing questions on how the inclusion of the entrepreneurial dimension affects the Uppsala model's predictions concerning speed, direction and level of commitment. Here we will just mention a few: what is the impact of liability of foreignness (and liability of outsidership) on firms' foreign investment behavior if we take entrepreneurial judgement based on a unique perception of the future seriously? To what extent are these liabilities barriers for the "Knightian entrepreneur" who believes that "he is right while everyone else is wrong" (Casson 1982:14)? Another intriguing issue is the extent to which entrepreneurial judgement itself can be an explanatory factor for differences between firms' internationalization behavior in addition to obvious factors like industry, firm size, global experience, networks, etc. (see e.g. Anderson 1993, 
Oviatt \& Dougall 1994, Petersen, Pedersen \& Sharma 2003, Riap, Riap \& Knight 2005, Johanson \& Vahlne 2009, Hennart 2013). After all, in line with the entrepreneurial logic described above, the “... essence of entrepreneurship is being different... because one has a different perception of the situation" (Casson 1982: 14). This opens up for an analysis of the internationalization process that focuses the individual manager rather than the firm.

One crucial issue is how entrepreneurial judgement, characterized by an effectuation logic, in combination with the entrepreneur's ability to expand opportunities through creative activities (Foss \& Klein 2012), will affect the speed and direction of firms' internationalization (Kalinic, Sarasvathy \& Forza 2014). This issue can be formulated in a somewhat provocative way: how relevant is incremental behavior, manifested in the speed and direction of internationalization, if entrepreneurship is fully integrated into the Uppsala model? These and other issues call for more research on the role of entrepreneurship in relation to the Uppsala model.

\section{BUSINESS NETWORK THEORY AND ENTREPRENEURSHIP}

It has been argued that the internationalization process is essentially an entrepreneurial one, “... because internationalization entails entry into new country markets. It may therefore be described as a process of innovation" (Jones \& Coviello, 2005: 287). This is also the view of the revised model: "As we have argued, internationalization resembles entrepreneurship and may be described as corporate entrepreneurship" (Johanson \& Vahlne, 2009: 1423). Consequently, the decision-making logic of the entrepreneur shaping the internationalization process becomes a major issue. However, in the revised model - in line with business network theory - internationalization is also a " relationship development process" (Johanson \& Vahlne 2009: 1419). This implies that a firm's foreign business is "completely" shaped by its business network. Do the entrepreneurial and business network view speak the same language in the model? 
Not necessarily. First, in the revised model the entrepreneur tends to apply an "effectuation logic" (Sarasvathy; 2001), that is, he/she starts with those means in his/her possession rather than with clearly defined goals. This has the implication that the opportunities are not only present and waiting to be discovered in the environment, but they can also be created by the entrepreneur. In relation to business network theory, this implies that the entrepreneur becomes less dependent on the existing network because a new network can be developed abroad which can used in the new international venture (Kalinic, Sasavarthy \& Forza, 2014). Consequently, the more the internationalization process is perceived to be an entrepreneurial process, and the more the entrepreneur applies an effectuation logic, the lower the impact of the liability of outsidership on the internationalization process for the simple reason that the entrepreneur does not primarily establish a position in an existing foreign network. Instead, a new network is created by the entrepreneur (Coviello 2006). This has much in common with the notion that in the early stages of the product life-cycle, vertical integration is more common because " ... the needs of the innovating firm are either too specialized or too difficult to communicate" (Langlois \& Robertson 1989: 374)².

Second, the business network view implies that close business relationships with customers and suppliers will facilitate both the discovery of opportunities, described as "unknown until discovered" (Shane 2000, p. 451), and the development of opportunities through interaction in these relationships (Johanson \& Vahlne 2009: 1419). However, from an entrepreneurial view this might look different. For instance as stated by Gargiulo \& Benassi: "The entrepreneurs... did benefit from the support and resources provided by their cohesive networks, but the obligations that resulted from these benefits, and the entrepreneurs' difficulties to extricate themselves from these obligations, curtailed their subsequent ability to pursue new opportunities. The social capital embodied in their cohesive networks then became a liability that hindered, rather than helped, their subsequent performance" (Gargiulo \& Benassi 2000: 185). A firm might hesitate to start a new business abroad if this were to mean that old relationships must be abandoned for new ones, despite the potential business opportunity having been discovered through the firm's existing network. With respect to opportunity development, therefore, one might expect that a firm embedded in a business network might suffer from the "liability of 
insidership". This reasoning has much in common with the notion that in a loosely constrained network, meaning a network in which the "insidership" is less pronounced, it is easier for the entrepreneur to develop and protect the basic business idea (Coviello, 2006).

Third, similar to the original model the revised Uppsala model is essentially a "learning-cycle" model (March and Olsen 1976; Leavitt \& March 1988; Forsgren 2002). Learning through feedback from previous experience of developing business relationships constitutes an important explanatory factor to firm's behavior. This also contributes to the path-dependence and incremental character of the model. An interesting issue is whether the entrepreneurship view is compatible with a learning-cycle model of this kind. Even if we lean towards a model of entrepreneurship more in line with "entrepreneurial judgement" described above, there is always a strong element associated with individual entrepreneurs' unexpected discoveries independent of their previous experience. The question is whether entrepreneurship in this sense harmonizes with a "learning cycle", or if, instead, behaving as an entrepreneur implies that there will inevitably be repeated "breaks" in the cycle with far-reaching consequences for the internationalization process in terms of pace, direction and commitment compared to to the ' 77 model.

\section{SOME FINAL REMARKS}

The revisited Uppsala internationalization process model represents a new perspective on internationalization more strongly than a specific model of firm's internationalization. One may even conclude that such a model is not needed, because firms' internationalization is fully captured in models of firms' general business behavior, for instance in models of how firms' grow by strengthening their position in business networks. However, if we assume that we need a full-fledged model dealing with the same issues as the ' 77 model - pace, direction and commitments of firms' foreign operations - the revisited model might, at best, provide a fruitful starting point for elaborating such a model. We suggest that any elaboration of this kind should consider certain important aspects: First, the concept liability of outsidership must be conceptualized in a way that allows for an analysis 
that goes beyond what is already inherent in the liability of foreignness. Second, rather than looking upon the business relationship development and the internationalization process as identical processes, a more fruitful approach would be to assume that they are different, but that they influence one another. Third, the role of entrepreneurship in the model is important, but a more suitable conceptualization of entrepreneurship based on Knight's approach is more fruitful than the one presented in the revisited model. Finally, the possibility to combine business network theory and entrepreneurship in one and the same model needs further consideration.

\section{Endnotes}

1. The authors maintain that networks are "borderless" and argue that internationalization has less to do with market entry than it has to do with improving positions in networks (Johanson and Vahlne 2009 , p. 1423.). This, in combination with the common notion in business network theory of networks being subjectively defined, makes the distinction between a firm's home network and foreign network somewhat blurred.

2. We are grateful to one of the reviewers for pointing this out.

\section{References}

Anderson, O. 1993. On the internationalization process of firms: A critical analysis. Journal of International Business Studies, 24(2):209-232

Andersson, U., Forsgren, M., Holm, U. 2002. The strategic impact of external networks: subsidiary performance and competence development in the multinational corporation. Strategic Management Journal 23(11): 979-996.

Autio, E., Sapienza, H.J., Almeida, I.G.2000. Effects of age at entry, knowledge intensity, and imitability on international growth. Academy of Management Journal, 43(5):909-924. 
Benito, G.R.G., Larimo, J., Narula, R., Pedersen, T. Multinational Enterprises from Small Economies: International Patterns of Large Companies from Denmark, Finland and Norway. International Studies of Management and Organization, 32(1): 57-78.

Blankenburg Holm, D., Johanson, M,, Kao, T.P. 2015. From outsider to insider: Opportunity development in foreign networks. Journal of International Entrepreneurship, 13: 337-359.

Burt, R. 1992. Structural Holes: The Social Structure of Competition. Cambridge: Harvard University Press.

Beugelsdijk, S., Mudambi, R. 2013. MNEs as border-crossing muti-location enterpreises: The role of discontinuities in geographic space. Journal of International Business Studies, 44: 413-426.

Casillas, J.C., Moreno-Menendez; A.M. 2014. Speed of the internationalization process: The role of diversity and depth in experiential learning. Journal of International Business Studies, 45: 85-101.

Casson, M. 1982. The Entrepreneur: An Economic Theory, second edition. Aldershot, UK: Edward Elgar.

Casson, M. 2003. The Entrepreneur. Cheltenham: Edward Elgar

Chamlee-Wright, E., Myers, J. 2008. Discovery and social learning in non-priced environments: An Austrian view of social network theory. Review of Austrian Economics, 21:151-166.

Coleman, J.S. 1988. Social capital in the creation of human capital. American Journal of Sociology, 94: $95-120$.

Conner, K.R., Prahalad, C.K. 1996. A resource-based view of the firm: knowledge versus opportunism. Organization Science, 7(5): 477-501.Coviello, N.E. 2006. The network dynamics of international new ventures. Journal of International Business Studies. 37:713-731

Dacin, T.M., Ventresca, M.J., Beal, B.D. 1999. The embeddedness of organizations: dialogue and direction. Journal of Management 25(3): 317-356. 
Figueria-de-Lemos, F., Johanson, J., Vahlne, J-E. 2011. Risk Management in the internationalization process of the firm: A note on the Uppsala model. Journal of World Business, 46: 143-153.

Ford, D. (ed) 1997. Understanding Business Markets. London: Dryden Press.

Forsgren, M. 2002. The concept of learning in the Uppsala internationalization process model: A critical view. International Business Review, 11(3). 257-278.

Forsgren, M., Holm, U., Johanson, J. 2005. Managing the Embedded Multinational: A business network view. Cheltenham: Edward Elgar.

Foss, N.J., Klein, P.G. 2010. Alertness, Judgement, and the Antecedents of Entrepreneurship. SMG WP, Copenhagen: Copenhagen Business School

Foss, N.J., Klein, P. 2012. Organizing Entrepreneurial Judgement. A New Approach to the Firm. Cambridge: Cambridge University Press.

Gargiulo, M., Benassi, M. 2000. Trapped in Your Own Net? Network Cohesion, Structural Holes, and the Adaptation of Social Capital. Organization Science 11(2): 183-196.

Grabher, G. 1993. Rediscovering the social in the economics of interfirm relations. In Grabher, G. (ed) The Embedded Firm. Routledge: London

Granovetter, M. 1983. The strength of weak ties: A network theory revisited. Sociological Theory, 1: 201-233.

Granovetter, M. 1985. Economic action and the social structure: the the problem of embeddedness. American Journal of Sociology, 91(3): 481-510.

Gulati, R. 1998. Alliances and Networks. Strategic Management Journal 19(4):293-317.

Gulati, R., Nohria, N., Zaheer, A. 2000. Strategic Networks. Strategic Management Journal, Special Issue 21: 203-215. 
Hansen, M.T. 1999. The search-transfer problem: the role of weak ties in in sharing knowledge across organization subunits. Administrative Science Quarterly 44(1): 82-111.

Hennart, J.F. 2013. The Accidental Internationalists: A Theory of Born Globals. ET\&P

Hymer, S. 1976. The International Operations of the National Firm. A Study of Foreign Direct Investments. Cambridge MA: MIT Press.

Håkansson, H., Snehota, I. 1995. Developing relationships in Business Networks. London: Routledge. Johanson, J., Vahlne, J.-E. 1977. The internationalization process of the firm: A model of knowledge development and increasing foreign commitments. Journal of International Business Studies, 8(1): 2332.

Johanson, J., Vahlne, J.E. 1990. The mechanism of internationalization. International Marketing Review, 7(4):11-24

Johanson, J., Vahlne, J.E. 2003. Business relationship learning and commitment in the internationalization process. Journal of international Entrepreneurship, 1(1):83-101.

Johanson, J., Vahlne, J.E. 2006. Commitment and opportunity development in the internationalization process: A note on the Uppsala internationalization process model. Management International Review, $46(2): 1-14$

Johanson, J., Vahlne, J.E. 2009. The Uppsala internationalization process model revisited: From liability of foreignness to liability of outsidership. Journal of International Business Studies, 40(x): $1411-1431$.

Jones, M.V. Coviello, N.E. 2005. Internationalization: conceptualizing an entrepreneurial process of behavior in time. Journal of International Business Studies, 36: 284-303.

Kalinic, I., Sarasvathy, A.D., Forza, C. 2014. Expect the unexpected: Implications of effectual logic on the internationalization process. International Business Review 23: 635-647. 
Kirzner, I. 1973. Competition and Entrepreneurship. Chicago: University of Chicago Press.

Kirzner, I.M. 1997. Entrepreneurial discovery and the competitive market process: An Austrian approach. Journal of Economic Literature, 35(1):60-85.

Kirzner, I.M. 2009. Mises and his Understanding of the Capitalist System. Cato Journal 19(2): 215232.

Kirzner, I., Sautet, F. 2006. Mercatus Policy Series, Policy Primer 4: 1-22.

Knight, F.H. 1921. Risk, Uncertainty and Profit. New York: August M. Kelly.

Krackhardt, D. 1990. Assessing the political landscape: structure, cognition and power in organizations. Administrative Science Quarterly 35: 342-369

Lane, P.J., Lubatkin, M. 1998. Relative absorbtive capacity and interorganizational learning. Strategic Management Journal 19(5): 461-477

Nahapiet, J., Ghoshal, S. 1998. Social capital, intellectual capital, and organizational advantage. Academy of Management Review 23(2): 242-266.

Langlois, R.N. 2007. The Entrepreneurial Theory of the Firm and the Theory of the Entrepreneurial Firm. Journal of Management Studies, 44(7): 1107-1124.

Langlois, R. N., Robertson, P.L. 1989. Explaining Vertical Integration: Lessons from the American Automobile Industry. The Journal of Economic History, 49 (2): 361-375.

Leavitt, B., March, J. G. 1988. Organizational Learning. Annual Review of Sociology 14: 319-340.

Mc Evily, B., Zaheer, 1999. Bridging ties: a source of firm heterogeneity in competitive capabilities. Strategic Management Journal 20 (12): 1133-1156.

March, J.G., Olsen, J.P. 1976. Organizational Learning and the Ambiguity of the Past. In March, J.G., Olsen, J.P. (Eds). Ambiguity and Choice in Organizations. Bergen: Universitetsforlaget. 
Moran, P. 2005. Structural vs Relational Embeddedness: Social Capital and Managerial Performance. Strategic Management Journal 26: 1129-1151.

Oehme, M., Bort, S. 2015. SME internationalization modes in the German biotechnology industry: The influence of imitation, network position, and the international experience. Journal of International Business Studies, 46: 629-655.

Oviatt, B.M., McDougall, P.P. 1994. Toward a theory of international new ventures. Journal of International Business Studies, 25(1): 45-64.

Petersen, B., Pedersen, T., Sharma, D.D. 2003. The role of knowledge in firms' internationalization process: Wherefrom and where to? In A. Blomstermo and D.D. Sharma (Eds) Learning in the internationalization process of firms: 36-55. Cheltenham: Edward Elgar.

Rialp, A., Rialp, J., Knight, G. 2005. The phenomenon of early internationalizating firms: What do we know after a decade (1993-2003) of scientific inquiry? International Business Review, 14: 147-166.

Santangelo, G.D., Meyer, K.E. 2011. Extending the internationalization process: Increases and decreases of MNE commitment in emerging economies. Journal of International Business Studies, 42: 894-909.

Sarasvathy, S.D. 2001. Causation and effectuation. Towards a theoretical shift from economic inevitability to entrepreneurial contingency. Academy of Management Review, 26(2): 243-263.

Shane, S. 2000. Prior knowledge and discovery of entrepreneurial opportunities. Organization Science, 11(4): 448-469.

Shane,S., Venkatraman, S. 2000. The Promise of Entrepreneurship a Field of Research. Academy of Management Review, 25: 217-226.

Schweizer, R., Vahlne, J.-E., Johanson, J. 2010. Internationalization as an entrepreneurial process. Journal of International Entrepreneurship 8: 343-370. 
Sui, S. Baum, M. 2014. Internationalization strategy, firm resources and the survival of SMEs in the export market. Journal of International Business Studies, 45: 821-841.

Vahlne, J.-E., Johanson, J. 2013. The Uppsala model on evolution of the multinational business enterpreise - from internalization to coordination of networks. International Marketing Review, 30(3): $189-210$.

Walker, G., Kogut, B., Shan, W. 1997. Social Capital, Structural Holes and the Foramtion of an Industry Network, Organization Science, 8(2): 109-125.

Uzzi, B. 1996. The Sources and Consequences of Embeddedness for the Economic Performance of Organizations: The Network Effect. American Sociological Review, 61:674-698.

Uzzi, B. 1997, Social Structure and Competition in Interfirm Networks; The Paradox of Embeddedness. Administrative Science Quarterly, 42: 35-67.

Zaheer, S.1995. Overcoming the liability of foreignness. Academy of Management Journal, 38(2): $341-363$ 